\title{
PREDICTORS OF ACADEMIC SUCCESS IN POSTGRADUATE AUDITING IN THE CHARTERED ACCOUNTANCY PROGRAMME AT A SOUTH AFRICAN UNIVERSITY
}

\author{
C. Crous*
}

Business School

https://orcid.org/0000-0001-6478-2804

\section{E. Goodchild*}

School of Accountancy

https://orcid.org/0000-0003-3753-4551

*University of the Free State

Bloemfontein, South Africa

\section{ABSTRACT}

South African universities that offer the accredited Chartered Accountancy [CA] programme are monitored by the South African Institute of Chartered Accountants (SAICA) to ensure that the programme meets SAICA's requirements in terms of the standards of teaching and learning. The monitoring includes a scrutiny of the academic success of students with regard to pass rates and throughput rates. This inevitably results in universities not only focussing on the academic success of students, but also predicting the success of their students. Much of the existing research focusses on the success of first-year students in the subject field of financial accounting, or success overall at postgraduate level. This article aims to bridge the gap in the research field by exploring academic predictors of success for postgraduate students in the accounting programme, with reference to a specific module - namely, auditing - at a South African university over a period of five years (2014-2018). The objectives are to determine the extent to which selected grade-12 subjects (maths and language); admission requirements, namely the Admission Point (AP) score and the National Benchmark Test (NBT); as well as undergraduate performance could predict the success of a postgraduate module. Drawing on quantitative data, the findings indicate that the grade- 12 subjects and admission requirements do not have a positive correlation with academic success, with only a few selected undergraduate level modules predicting academic success.

Keywords: student success, predictor of success, admission requirements, national benchmark test, postgraduate level, correlation

\section{INTRODUCTION}

In 2019, the South African Institute of Chartered Accountants (SAICA) announced a pass rate of 71 per cent for the Initial Test of Competence (ITC) examination written in January 2019, 
the first of two examinations for aspiring Chartered Accountants [CA(SA)s] (SAICA 2019). The ITC pass rate is rightfully celebrated in the Chartered Accountancy profession. The ITC pass rate may, however, not be a true reflection of the challenges that accounting departments at universities face in respect of the poor academic performance of students during the academic programme, in preparation for the ITC examinations. The academic programme in view of becoming eligible for writing the ITC examinations entails a three-year undergraduate degree followed by a one-year postgraduate programme known as the Certificate in the Theory of Accounting (CTA) (Terblanche and Waghid 2020).

For academic programmes accredited by SAICA to offer the CTA programme, the ITC results play a crucial role in the design of accounting degrees as well as the related pedagogy (De Villiers and Venter 2013; Terblanche and Waghid 2020; Wood and Maistry 2014). De Villiers and Venter (2013) raise criticism against the significant influence of this accounting body on the academic freedom of universities. The design of accounting degrees at universities, accredited by SAICA to offer the CTA qualification, is thus mostly similar and is explained by institutional theory and how the external environment (SAICA) leads to the corresponding development of structures and processes (academic programmes) (Boland, Sharma and Afonso 2008; Cai 2015).

The number of research initiatives undertaken in the past few years investigating the possible predictors of success of accounting students at higher education institutions (HEI) (Baard et al. 2010; Jansen and De Villiers 2015; Matarirano et al. 2019; Muller and Prinsloo 2007; Rossouw 2018; Ungerer et al. 2013) illustrates that it is a contentious issue in South Africa. This has resulted in a large and growing body of literature on the underlying predictors of academic success for students in accounting programmes.

The literature search yielded many South African studies pertaining to success predictors of accounting students in particular. It is evident that many of the studies presented investigate both academic and non-academic factors as possible predictors of success. The authors take cognizance that no single factor can predict the academic success of students. In addition, the authors acknowledge the importance of the holistic development of students and that other nonacademic factors have a significant impact on the prediction of academic success, including the use of open book-assessments in writing examinations (Kruger 2020) as well as the different types of academic support activities (Ontong, Waal and Wentzel 2020). However, for the purposes of this article, the focus will only be on the academic predictors of student success.

Current research pays particular attention to the predictors of academic success in accounting as a subject, with specific reference to the first-year level. However, some studies did focus to a limited extent on the predictors of success for a specific module at postgraduate 
level. Based on the literature search, and to the best of the authors' knowledge, only a few research projects have so far been performed in view of predicting the academic success of specific postgraduate level modules. It follows therefore that the focus of this article is to investigate the extent to which selected academic indicators could predict the success of postgraduate students in the accounting programme - with specific reference to the subject of auditing.

\section{LITERATURE REVIEW}

Previous studies relating to the prediction of student success in accounting studies, include academic factors such as high school grades, past performance in undergraduate studies, numeracy skills, language proficiency and maths marks. Non-academic predictors also feature often in literature and include factors such as age, gender, race, type of school attended, personality, socio-economic background, class attendance and type and number of assessments used. The extant South African literature mainly focusses on the academic success of undergraduate students. Bruwer and Ontong (2020), Oosthuizen and Eiselen (2012), Matarirano et al. (2019), Papageorgiou (2017) and Papageorgiou and Carpenter (2019) investigated the factors influencing the success of first year accounting students. This included non-academic factors such as the location of the school the students attended, age, race and gender. The academic factors they considered included language proficiency, grade 12 marks (not limited to maths only) and level of knowledge on accounting specifically. Papageorgiou (2017) found that the prior knowledge of accounting was a predictor of academic success, thus supporting the international literature that prior knowledge of a subject is a predictor of later academia success (Gammie, Jones and Robertson-Millar 2003; Huang 2011; Onay and Benligiray 2018).

Studies that investigate prediction of postgraduate studies success while using undergraduate results are limited. Bruwer and Ontong (2020) investigated the impact of early assessments as a predictor in specific two first year accounting modules. Papageorgiou and Carpenter (2019) focussed on the importance of prior accounting knowledge on first year accounting students. Similarly other studies also focussed on first year students (Oosthuizen and Eiselen 2012; Matarirano et al. 2019; Rossouw 2018). Jansen and De Villiers (2015) investigated the importance of grade 12 subjects, age, gender and type of school attended for third year students only, but excluded prior academic results from their study. Although Steenkamp (2014) and Ungerer et al. (2013) investigated the prediction of success for postgraduate studies, only Steenkamp (2014) included past undergraduate academic performance in her study.

Gammie et al. (2003) as well as Buckless and Krawczyk (2016) confirms the statistical 
importance of undergraduate performance on the prediction of postgraduate success and reports that the majority studies use an average of grades for performance. Zimmerman et al. (2015) used first, second and third-year modules in their investigation into predicting the postgraduate success of students in a Computer Science degree. Their study resulted in explaining 54 per cent of the variance in postgraduate performance by looking at undergraduate performance. No similar study on the use of individual undergraduate models for accounting modules, could be identified.

\section{Academic predictors of success}

The definition of student academic success could be elusive (Alyahyan and Düştegör 2020; Gammie et al. 2003). Alyahyan and Düştegör $(2020,3)$ synthesized the definition from literature as "Student success is defined as academic achievement, engagement in educationally purposeful activities, satisfaction, acquisition of desired knowledge, skills competencies, persistence, attainment of educational outcomes, and post-college performance". Others characterize academic success ranging from academic (past academic performance at school and university level); non-academic (background, study behaviour, class attendance, confidence, self-discipline (Barnes, Dzansi, and Viljoen 2009; Sadler and Erasmus 2005); intrinsic (i.e., how students construct knowledge, study behaviour (Myers 2016) and extrinsic factors (i.e., the availability of study time and teaching support (Papageorgiou and Callaghan 2018)

Steenkamp (2014) used the marks a student obtained in the third year of study for an accounting module as well as whether the student completed the module in the prescribed timeframe as proxies for previous performance, thus focussing only on the prior results of one module. Bruwer and Ontong (2020) divided their samples into high performing and low performing students. They classified students with a mark of less than 50 per cent as low performing and those that achieved a mark of more than 50 per cent as high performing students. Ungerer et al. (2013) defined academic success at postgraduate level as those students who achieved a final mark of more than 49 per cent and they included students who attempted the modules more than once, thus a pass mark regardless of the number of attempts at a module.

Academic success in this article is defined as passing a module on the student's first attempt with a mark of 50 per cent or more. The specific academic predictors used in this article to investigate the correlation between academic performance and postgraduate student success are: 1) Grade-12 results with reference to mathematics and language as subjects, 2) the admission requirements used by the university (AP and NBT), as well as 3) performance in undergraduate modules of the academic programme. A brief motivation for the selection of 
each of these three academic predictors are provided below.

\section{Grade 12 results: Mathematics and Languages}

Many research projects undertaken use maths and language in high school as possible predictors of success (Botha, Mccrindle and Owen 2003; Eiselen, Strauss and Jonck 2007; Lourens and Smit 2004; Maurice 2015; Muller 2013; Rankin, Schoer and Sebastiao 2012; Van Zyl 2010; Woloschuk, McLaughlin and Wright 2010). Also, even though the requirements do vary from university to university, the minimum requirements into the accountancy programme include the subjects Mathematics and English (SAICA 2018).

The very notion that performance in mathematics and language correlate with academic success (or failure) of students is, however, being re-examined (Drennan and Rohde 2002; Van der Westhuizen and Barlow-Jones 2015; Visser and Zyl 2013). Previous research findings illustrate the inconsistencies and contradictory views about the correlation, with specific reference to accounting students. A number of studies found a positive correlation between (mathematics and language) and the academic success of undergraduate and postgraduate accounting students respectively (Maurice 2015; Oosthuizen and Eiselen 2012; Rossouw 2018; Swart and Becker 2014). Other research studies provide evidence to the contrary, namely that there is no statistical or an insignificant correlation between maths and language and success of accounting students, at first-year level (Matarirano et al. 2019), accounting third-year level (Jansen and De Villiers 2015) or at CTA level (Steenkamp 2014). The contradictory research outcomes intensify the quest for finding trustworthy and reliable predictors of academic success. The first objective of this article is to investigate the correlation between maths and language results in grade 12 and postgraduate performance in auditing. We, therefore, posit the following:

- Hypothesis 1: There is a positive relationship between grade 12 mathematics and languages and success in auditing at postgraduate level.

\section{Admission requirements}

Universities in South Africa make use of two indicators of possible success for admission into their programmes, namely the Admissions Point (AP) which is based on previous scholastic achievement and the National Benchmark Test (NBT) (Papageorgiou 2017). The use of AP scores as an admission requirement is increasingly challenged by scholars, as it relies on school results that are provided by a perceived ailing school system (Jansen 2012; Van der Westhuizen and Barlow-Jones 2015). The South African school system has been described by many as 
"broken and unequal" (Amnesty International 2020,1) "one of the worst in the world" (Editorial Staff 2017); “in tatters" (Monare 2010, 10) and "poorly functioning” (Taylor 2006, $2-3)$.

To supplement the use of the AP score, many universities have adopted alternative measures to independently measure basic mathematical skills (Eiselen et al. 2007). Prospective South African HEI students must write the NBT which aims to provide information about the preparedness of students to succeed academically (Du Plessis and Gerber 2012; HESA 2006; Van der Westhuizen and Barlow-Jones 2015; Wilson-Strydom 2012). The NBT is similar to the Scholastic Aptitude Test (SAT) and the American College Test (ACT) (Huang 2011).

When applicants are admitted (based on the mentioned admission requirements) to an HEI, there is a tacit assumption that they will be capable of completing the course for which they are permitted to enrol (Fraser and Killen 2003). Literature also provides mixed results about the accuracy of these tests to predict academic success (Huang 2011). Supporting these mixed results and as experienced academics in the accounting programme for a significant number of years, the authors have observed that a high AP score and NBT results do not necessarily result in a higher success rate of students. The question therefore arises: If the AP score and the NBT are not reliable admission requirements and possible indicators of success then what is? The second objective of this article is, therefore to establish the correlation between [the AP and NBT results] and postgraduate success in auditing. Hence, we posit that:

- Hypothesis 2: There is a positive relationship between admission requirements (AP score and NBT results) and success in auditing at postgraduate level.

\section{Undergraduate performance predicting postgraduate success}

International literature indicates the importance of "academic tendency" as an indicator of academic success. Defining academic tendency, much like academic performance, is a difficult task. Onay and Benligiray (2018) identify a Grade Point Average (GPA) over three different accounting levels as an important indicator of previous academic success for more senior modules. Zimmerman et al. (2015) calculated a GPA over three years of modules in a Bachelor of Computer Science program and found a significant statistical correlation between undergraduate and postgraduate performance. Other studies also recognizes that the success of undergraduate modules could possibly predict success in modules at postgraduate level (Duff 2007; Steenkamp 2014; Sulaiman and Mohezar 2006), whereas some studies provide that it is not indicative of success (Woloschuk et al. 2010).

Alyahyan and Düştegör (2020) confirmed that the inclusion of individual year modules in 
the prediction of academic success, creates a more accurate prediction model, especially if more than two years of academic data is used. They found that including year levels in prediction models can improve the accuracy of the prediction from 62 per cent to 89 per cent. Additionally, they showed that the inclusion of previous experience in a field increased accuracy of academic success to 93 per cent (Alyahyan and Düştegör 2020). The question remains if undergraduate modules or courses, either individually or in aggregate, are indicative of success for auditing at postgraduate level. Hence, we posit that:

- Hypothesis 3: There is a positive relationship between undergraduate accountancy performance and success in auditing at postgraduate level.

\section{RESEARCH METHOD AND DATA}

Student data for this research were obtained from the relevant accounting department for the years 2014 until 2018. The results for each student were analyzed and only the mark for the first attempt was retained, as a successful student was classified as a student that passed the module on the first attempt with 50 per cent or more. Excluded from the list were students who matriculated in 2008 or earlier, as that school curriculum differed from the current system. The student list of the CTA class list was used to create the database of the complete results for each student, which included the grade-12 mathematics and language marks, the AP and NBT scores as well as the results of all the undergraduate accountancy modules. Table 1 contains the variables and their definitions used for this study.

Table 1: Variable definitions

\begin{tabular}{|l|l|}
\hline \multicolumn{1}{|c|}{ Variable } & \multicolumn{1}{c|}{ Definition } \\
\hline Dependent variable \\
\hline PGAUD & $\begin{array}{l}\text { Postgraduate Auditing, at an advanced level in preparation for the SAICA Initial Test of } \\
\text { Competences }\end{array}$ \\
\hline Independent variables \\
\hline $\mathbf{1}^{\text {st }}$ Year level & \multicolumn{2}{|l|}{ Matric results for English } \\
\hline ENG & Matric results for Afrikaans \\
\hline AFR & Matric results for Mathematics \\
\hline MATHS & Acceptance Point score calculated based on institutional admission requirements \\
\hline AP & National Benchmark score for Mathematics \\
\hline NBT-AL & National Benchmark score for Language \\
\hline NBT-ML & Introduction to financial accounting semester 1 \\
\hline FACS1 & Introduction to financial accounting semester 2 \\
\hline FACS2 & Computer applications ${ }^{1}$ \\
\hline CAPP &
\end{tabular}




\begin{tabular}{|l|l|}
\hline \multicolumn{1}{|c|}{ Variable } & \\
\hline $2^{\text {nd }}$ Year level & \multicolumn{1}{c|}{ Definition } \\
\hline FACS3 & Financial accounting second year \\
\hline MANAC & Introduction to managerial accounting \\
\hline BUSE & Business ethics \\
\hline TAX & Introduction to taxation \\
\hline MANAF & Introduction to managerial finance \\
\hline AUD2 & Introduction to external auditing \\
\hline $3^{\text {rd }}$ Year level & \\
\hline FACS4 & Financial accounting \\
\hline AUD3 & External auditing \\
\hline TAX3 & Taxation \\
\hline MANAAF & Managerial accounting and finance \\
\hline General & \multicolumn{2}{|l}{} \\
\hline Sq & Square of a variance for non-linear relationships \\
\hline
\end{tabular}

To investigate Hypothesis one to three, multiple regression analyses were performed. The grade 12 mathematics and language results, AP Score and NBT results were included in the regression of first-year modules, as these aspects are used for admission to university. Several models were tested for each academic year, starting with a baseline model that includes all independent variables (Model 1 of each academic year).

Based on the results of the baseline models, it became clear that there may be non-linear relationships between the independent variables and the dependent variable. For this reason, the squares of the independent variable were included and the regression analysis was reperformed. Based on the results, only significant variables were included in the adjusted models, in an attempt to identify the multiple regression model that best predicts success. This was done based on the significance of each variable. Each model was then applied to the student cohorts, in order to identify which model is the best predictor of academic success. The models identified and tests for each academic year are as follows:

\section{$1^{\text {st }}$ Academic year models}

Baseline model:

$P G A U D=$

$\beta 0+\beta 1 E N G+\beta 2 A F R+\beta 3 M A T H S+\beta 4 A P+\beta 5 N B T-A L+\beta 6 N B T-A L+\beta 7 F A C S 1+\beta 8 F A C S 2+\beta 9 C A P P$

Model 2:

$P G A U D=\beta 0+\beta 1 \beta 7 F A C S 1$ 


\section{$2^{\text {nd }}$ Academic year models}

Baseline model:

$P G A U D=\beta 0+\beta 1 F A C 3+\beta 2 M A N A C+\beta 3 B U S E+\beta 4 T A X+\beta 5 M A N A F+\beta 6 A U D 2$

Model 2:

$P G A U D=\beta 0+\beta 1 M A N A C+\beta 2 M A N A C s q+\beta 3 M A N A F+\beta 4 A U D 2+\beta 5 A U D 2 s q$

Model 3:

$P G A U D=\beta 0+\beta 1 F A C S 3+\beta 2 F A C S 2 s q+\beta 3 M A N A F+C A P P$

Model 4:

$P G A U D=\beta 0+\beta 1 F A C 3$

Model 5:

$P G A U D=\beta 0+\beta 1 A U D 2+\beta 2 A U D 2 s q$

\section{$3^{\text {rd }}$ Academic year models}

Baseline model:

$P G A U D=\beta 0+\beta 1 F A C S 4+\beta 2 A U D 3+\beta 3 T A X 3+\beta 4 M A N A A F$

Model 2:

$P G A U D=\beta 0+\beta 1 F A C S 4+\beta 2 E F A C S s q+\beta 3 A U D 3$

Model 3:

$P G A U D=\beta 0+\beta 1 T A X 3+\beta 2 M A N A A F+\beta 3 M A N A A F s q$

Model 4:

$P G A U D=\beta 0+\beta 1 F A C S 4$

Model 5:

$P G A U D=\beta 0+\beta 1 M A N A A F$ 


\section{EMPIRICAL RESULTS AND DISCUSSION}

\section{Descriptive statistics}

Table 2 provides an overview of the mean, median and standard deviation of each of the independent variables for each of the five years, 2014 to 2018. Apart from FACS1, FACS2, TAX and FACS4, all variables show a decrease in the standard deviation from 2015 to 2016. This may be explained by the adjustment of marks at the end of 2015 and portions of 2016 due to the impact of student protests and the Fees-must-Fall campaign that caused this university to close down for portions of those two financial years. Assessment in those two years also differed from the assessments in 2014, 2017 and 2018, because mitigating and alternative assessments were implemented to counter the effect of the closure. The standard deviation from 2016 to 2017 remained fairly constant, with the exception of a significant increase in the standard deviation of FACS1 and TAX from 2016 to 2017. The standard deviations in 2018 returned to the levels they were at in 2015, indicating that the effects of the student protests experienced in 2015 and 2016 had faded.

Table 3 reports a significant correlation between the independent variables. There appears to be a negative correlation between TAX2 and grade-12 languages as well as TAX2 and all third academic year variables. Only the correlation between TAX2 and AUD3 seems to be significant at a 1 per cent level. The high correlation between the majority of the variables (larger than 0.700) is expected, as the modules are presented in the same department, and the module in the first academic year serves as prerequisite for the modules in the second academic year and further. No adjustments were therefore made for possible multi-collinearity or heteroscedasticity in the study.

\section{Regression analysis}

\section{First-year modules}

Table 4 presents the results of the two regression models for the first academic year for the 2014 to 2018 cohorts. Based on Model 1 (baseline model), CAPP is statistically significant for the 2015 and 2017 cohorts. ENG is statistically significant for the 2017 cohort and NBT-AL is statistically significant for the 2017 and 2018 cohorts. These results are contrary to the results of Swart and Becker (2014) who found a positive correlation between academic performance at school level and postgraduate success. NBT-ML is statistically significant for the 2017 cohort only, adding to the international mixed literature on the use of admission tests to identify 
Table 2: Descriptive statistics per year

\begin{tabular}{|c|c|c|c|c|c|c|c|c|c|c|c|c|c|c|c|}
\hline & \multicolumn{3}{|c|}{2014} & \multicolumn{3}{|c|}{2015} & \multicolumn{3}{|c|}{2016} & \multicolumn{3}{|c|}{2017} & \multicolumn{3}{|c|}{2018} \\
\hline & Mean & Median & $\begin{array}{c}\text { Std. } \\
\text { Deviation }\end{array}$ & Mean & Median & $\begin{array}{c}\text { Std. } \\
\text { Deviation }\end{array}$ & Mean & Median & $\begin{array}{c}\text { Std. } \\
\text { Deviation }\end{array}$ & Mean & Median & $\begin{array}{c}\text { Std. } \\
\text { Deviation }\end{array}$ & Mean & Median & $\begin{array}{c}\text { Std. } \\
\text { Deviation }\end{array}$ \\
\hline & \multicolumn{3}{|c|}{$(N=133)$} & \multicolumn{3}{|c|}{$(N=96)$} & \multicolumn{3}{|c|}{$(N=119)$} & \multicolumn{3}{|c|}{$(N=147)$} & \multicolumn{3}{|c|}{$(N=88)$} \\
\hline AP & 33.30 & 37.00 & 11.855 & 34.08 & 37.50 & 12.615 & 35.29 & 36.00 & 7.876 & 36.34 & 37.00 & 8.449 & 34.58 & 36.00 & 10.179 \\
\hline AFR & 49.60 & 68.00 & 35.324 & 55.68 & 73.50 & 35.158 & 51.98 & 65.00 & 33.028 & 51.91 & 67.00 & 34.650 & 58.13 & 73.00 & 31.836 \\
\hline 12 ENG & 63.19 & 70.00 & 22.450 & 65.76 & 71.50 & 21.582 & 68.51 & 69.00 & 13.248 & 70.67 & 73.00 & 15.242 & 70.00 & 17.04 & 15.817 \\
\hline MATHS & 66.23 & 73.00 & 26.690 & 67.14 & 73.50 & 24.075 & 66.67 & 70.00 & 18.357 & 68.49 & 72.00 & 18.545 & 67.72 & 72.50 & 19.021 \\
\hline NBT-AL & 40.16 & 55.00 & 31.047 & 38.82 & 55.00 & 31.685 & 44.37 & 55.00 & 27.565 & 48.05 & 57.00 & 26.645 & 50.98 & 59.50 & 26.839 \\
\hline NBT-ML & 29.51 & 34.00 & 24.918 & 29.28 & 35.00 & 24.959 & 32.78 & 37.00 & 22.208 & 39.05 & 43.00 & 24.386 & 42.02 & 46.00 & 25.682 \\
\hline FACS1 & 0.52 & 0.00 & 5.983 & 0.00 & 0.00 & 0.000 & 6.39 & 0.00 & 21.262 & 15.31 & 0.00 & 30.527 & 13.56 & 0.00 & 30.307 \\
\hline FACS2 & 0.42 & 0.00 & 4.856 & 0.82 & 0.00 & 8.063 & 37.54 & 53.00 & 36.630 & 3.96 & 0.00 & 16.762 & 4.26 & 0.00 & 17.504 \\
\hline CAPP & 0.00 & 0.00 & 0.00 & 38.71 & 56.50 & 37.343 & 53.50 & 63.00 & 30.674 & 67.74 & 71.00 & 20.402 & 64.80 & 75.00 & 28.393 \\
\hline FACS3 & 34.43 & 55.00 & 31.32 & 36.64 & 58.00 & 35.055 & 45.67 & 60.00 & 32.501 & 51.10 & 58.00 & 25.234 & 48.82 & 56.00 & 27.450 \\
\hline BUSE & 0.00 & 0.00 & 0.00 & 37.10 & 53.00 & 37.086 & 49.08 & 64.00 & 32.025 & 63.08 & 67.00 & 19.092 & 60.01 & 70.50 & 27.275 \\
\hline TAX & 0.50 & 0.00 & 5.723 & 0.00 & 0.00 & 0.000 & 2.76 & 0.00 & 14.935 & 54.65 & 75.00 & 36.263 & 62.91 & 73.00 & 26.860 \\
\hline MANAF & 0.00 & 0.00 & 0.00 & 40.01 & 58.00 & 34.643 & 53.72 & 64.00 & 28.469 & 66.93 & 73.00 & 21.328 & 65.36 & 74.50 & 28.158 \\
\hline AUD2 & 0.46 & 0.00 & 5.289 & 40.35 & 63.50 & 36.904 & 49.88 & 66.00 & 31.818 & 55.41 & 64.00 & 26.351 & 62.19 & 73.00 & 32.421 \\
\hline FACS4 & 34.43 & 55.00 & 31.320 & 44.06 & 55.00 & 27.438 & 42.13 & 56.00 & 29.122 & 48.22 & 55.00 & 24.409 & 43.90 & 52.00 & 25.364 \\
\hline AUD3 & 33.85 & 53.00 & 31.710 & 44.20 & 55.00 & 26.691 & 39.34 & 53.00 & 27.267 & 50.73 & 59.00 & 25.686 & 48.91 & 60.00 & 27.798 \\
\hline TAX3 & 35.29 & 56.00 & 32.575 & 45.68 & 57.50 & 28.112 & 42.47 & 55.00 & 29.514 & 52.38 & 62.00 & 26.501 & 48.55 & 58.00 & 27.591 \\
\hline MANAAF & 39.07 & 60.00 & 36.096 & 49.85 & 62.00 & 30.296 & 43.56 & 57.00 & 30.204 & 51.13 & 57.00 & 25.979 & 45.45 & 55.00 & 25.732 \\
\hline
\end{tabular}


Table 3: Correlation matrix

\begin{tabular}{|c|c|c|c|c|c|c|c|c|c|c|c|c|c|c|c|c|c|c|c|}
\hline & $\frac{0}{<}$ & $\frac{\frac{r}{4}}{\frac{L}{\alpha}}$ & 导 & $\frac{\infty}{\frac{\infty}{5}}$ & $\begin{array}{l}\frac{\vec{r}}{\mathbf{s}} \\
\frac{\mathbf{m}}{\mathbf{z}}\end{array}$ & $\begin{array}{l}\underset{i}{\frac{1}{1}} \\
\frac{\mathbf{m}}{z}\end{array}$ & $\begin{array}{l}\bar{\delta} \\
\bar{L} \\
\overline{4}\end{array}$ & 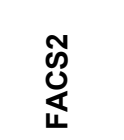 & $\frac{a}{\frac{0}{\delta}}$ & 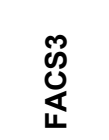 & $\frac{0}{\frac{0}{k}}$ & 峁 & $\underset{\leftarrow}{\stackrel{x}{\leftarrow}}$ & $\frac{L}{\frac{L}{5}}$ & Оิ & 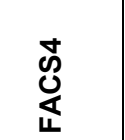 & $\stackrel{\text { O̊ }}{\frac{m}{4}}$ & 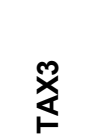 & $\begin{array}{l}\frac{u}{4} \\
\frac{\pi}{2} \\
\frac{4}{2}\end{array}$ \\
\hline $\mathbf{A P}$ & 1 & & & & & & & & & & & & & & & & & & \\
\hline AFR & $0.453^{* *}$ & 1 & & & & & & & & & & & & & & & & & \\
\hline ENG & $0.825^{* *}$ & $0.440^{* *}$ & 1 & & & & & & & & & & & & & & & & \\
\hline MATHS & $0.758^{* * *}$ & $0.408^{* \prime}$ & $0.742^{\prime \prime \prime}$ & 1 & & & & & & & & & & & & & & & \\
\hline NBT-AL & $0.504^{* * *}$ & $0.449^{\prime *}$ & $0.447^{* *}$ & $0.444^{\prime *}$ & 1 & & & & & & & & & & & & & & \\
\hline NBT-ML & $0.519^{* * t}$ & $0.400^{* *}$ & $0.434^{* *}$ & $0.526^{* *}$ & $0.890^{* *}$ & 1 & & & & & & & & & & & & & \\
\hline FACS1 & $0.340^{* * *}$ & $0.164^{* *}$ & $0.311^{* *}$ & $0.295^{* *}$ & $0.354^{* *}$ & $0.435^{* *}$ & 1 & & & & & & & & & & & & \\
\hline FACS2 & $0.265^{* *}$ & $0.090^{*}$ & $0.253^{* *}$ & $0.218^{* *}$ & $0.297^{* *}$ & $0.329^{* *}$ & $0.741^{* *}$ & 1 & & & & & & & & & & & \\
\hline CAPP & $0.341^{* *}$ & $0.216^{* *}$ & $0.349^{* *}$ & $0.276^{* *}$ & $0.316^{* *}$ & $0.349^{* *}$ & $0.591^{* *}$ & $0.556^{* *}$ & 1 & & & & & & & & & & \\
\hline FACS3 & $0.377^{* * t}$ & $0.221^{* \prime}$ & $0.352^{2 *}$ & $0.329^{* *}$ & $0.386^{* *}$ & $0.429^{* *}$ & $0.649^{* *}$ & $0.619^{* *}$ & $0.853^{* *}$ & 1 & & & & & & & & & \\
\hline MANAC & $0.309^{* *+}$ & $0.179^{* \prime}$ & $0.348^{* \prime}$ & $0.240^{* \prime}$ & $0.300^{* *}$ & $0.329^{* *}$ & $0.551^{* *}$ & $0.503^{* *}$ & $0.900^{* \prime}$ & $0.801^{* \prime}$ & 1 & & & & & & & & \\
\hline BUSE & $0.359^{* * *}$ & $0.227^{* \prime}$ & $0.347^{* \prime \prime}$ & $0.270^{\circ *}$ & $0.357^{* *}$ & $0.378^{* \prime}$ & $0.588^{* \prime \prime}$ & $0.550^{* *}$ & $0.947^{* \prime}$ & $0.852^{2 *}$ & $0.880^{* *}$ & 1 & & & & & & & \\
\hline TAX2 & 0.019 & -0.049 & 0.048 & -0.027 & 0.053 & -0.008 & $0.204^{* *}$ & $0.322^{* *}$ & $0.185^{* *}$ & $0.160^{* *}$ & $0.349^{* *}$ & $0.190^{* *}$ & 1 & & & & & & \\
\hline MANAF & $0.335^{* *}$ & $0.199^{* *}$ & $0.354^{4 *}$ & $0.275^{* *}$ & $0.338^{* *}$ & $0.379^{* *}$ & $0.608^{* *}$ & $0.557^{* *}$ & $0.936^{* *}$ & $0.822^{2 *}$ & $0.931^{* *}$ & $0.917^{* *}$ & $0.222^{* *}$ & 1 & & & & & \\
\hline EAUD2 & $0.364^{* *}$ & $0.219^{* *}$ & $0.347^{* *}$ & $0.282^{* *}$ & $0.380^{* *}$ & $0.407^{* *}$ & $0.625^{* *}$ & $0.557^{* *}$ & $0.846^{* *}$ & $0.932^{2 *}$ & $0.797^{* *}$ & $0.853^{* *}$ & $0.171^{* *}$ & $0.829^{* *}$ & 1 & & & & \\
\hline FACS4 & $0.503^{* *}$ & $0.293^{* *}$ & $0.442^{* *}$ & $0.517^{* \prime}$ & $0.429^{* *}$ & $0.4566^{* \prime}$ & $0.471^{* *}$ & $0.456^{* *}$ & $0.502^{* *}$ & $0.687^{* \prime}$ & $0.412^{* *}$ & $0.500^{* *}$ & -0.025 & $0.467^{\prime \prime}$ & $0.623^{* *}$ & 1 & & & \\
\hline AUD3 & $0.508^{* *}$ & $0.319^{* *}$ & $0.454^{* \prime}$ & $0.506^{* *}$ & $0.461^{* *}$ & $0.477^{* *}$ & $0.479^{* *}$ & $0.450^{* *}$ & $0.525^{\prime \prime}$ & $0.680^{\circ *}$ & $0.416^{* *}$ & $0.524^{* *}$ & $-0.088^{*}$ & $0.486^{* *}$ & $0.642^{* *}$ & $0.957^{* *}$ & 1 & & \\
\hline TAX3 & $0.509^{* * *}$ & $0.323^{* *}$ & $0.452^{2 *}$ & $0.514^{* *}$ & $0.443^{\text {t* }}$ & $0.467^{* *}$ & $0.489^{* *}$ & $0.464^{* *}$ & $0.526^{* *}$ & $0.695^{* *}$ & $0.426^{* *}$ & $0.524^{4 *}$ & -0.069 & $0.493^{* *}$ & $0.643^{* *}$ & $0.974^{* *}$ & $0.973^{* *}$ & 1 & \\
\hline MANAAF & $0.522^{* *}$ & $0.355^{* *}$ & $0.455^{* *}$ & $0.530^{* *}$ & $0.455^{* *}$ & $0.481^{* *}$ & $0.424^{* *}$ & $0.411^{* *}$ & $0.461^{* *}$ & $0.639^{* *}$ & $0.367^{* *}$ & $0.464^{4 *}$ & -0.068 & $0.424^{* *}$ & $0.584^{* *}$ & $0.967^{* *}$ & $0.956^{* *}$ & $0.974^{* *}$ & 1 \\
\hline
\end{tabular}

${ }^{* *}$ Correlation is significant at the 0.01 level (2-tailed).

* Correlation is significant at the 0.05 level (2-tailed). 
student success. FACS2 is statistically significant for the 2018 cohort only. The baseline model can therefore not be used to predict the success of students in the PGAUD.

When model 2 is applied to the cohorts, only FACS2 is statistically significant for all five cohort groups. FACS2 had a statistically negative relationship to PGAUD for the 2014 and 2018 cohorts; but a statistically positive relationship in 2016 and 2017. The difference in the direction of the relationship may be the impact of the student protests of 2015 and 2016, but the cause of the change of direction was not investigated. The low adjusted $\mathrm{R}^{2}$ of model 2 for all cohorts (less than $12 \%$ ) is an indication that the proposed model can explain merely 12 per cent of the success of a student.

This is an indication that other factors also influence the success of students in the first academic year, which may include supportive courses such as economics, statistics and law, as well as non-academic factors reported by Papageorgiou (2017) and others. Hypotheses 1 and 2 are therefore rejected, as the grade 12 mathematics and language results, AP score and the NBT results are not found to be statistically significant indicators of success for the PGAUD module in the first academic year. Hypothesis 3 is also rejected in relation to first-year academic models, because there is no indication that first-year models have a significant positive relationship with success in PGAUD.

Table 4: Regression analysis, first-year modules

\begin{tabular}{|c|c|c|}
\hline & Model 1 (Baseline model) & Model 2 \\
\hline \multicolumn{3}{|c|}{2014} \\
\hline Constant & $\begin{array}{c}37.404^{*} \\
(0.000)\end{array}$ & $\begin{array}{c}45.182^{*} \\
(0.000)\end{array}$ \\
\hline ENG & $\begin{array}{l}-0.185 \\
(0.167)\end{array}$ & \\
\hline AFR & $\begin{array}{c}0.074 \\
(0.142)\end{array}$ & \\
\hline MATHS & $\begin{array}{c}0.038 \\
(0.685) \\
\end{array}$ & \\
\hline$\overline{\mathrm{AP}}$ & $\begin{array}{c}0.384 \\
(0.153)\end{array}$ & \\
\hline NBT-AL & $\begin{array}{c}-0.013 \\
(0.906) \\
\end{array}$ & \\
\hline NBT-ML & $\begin{array}{c}0.033 \\
(0.817)\end{array}$ & \\
\hline FACS2 & $\begin{array}{l}-0.704 \\
(0.012)\end{array}$ & $\begin{array}{c}-0.807 \\
(0.004)^{*}\end{array}$ \\
\hline ADJUSTED R² & 0.093 & 0.054 \\
\hline Std. Error of Estimation & 15.145 & 15.473 \\
\hline F-statistic & 2.937 & 8.462 \\
\hline ANOVA Sig. & 0.007 & $0.004^{*}$ \\
\hline \multicolumn{3}{|c|}{2015} \\
\hline Constant & $\begin{array}{l}46.724^{*} \\
(0.000)\end{array}$ & \multirow[t]{2}{*}{$\begin{array}{l}\text { No results, as the module FACS2 } \\
\text { was not presented in this year }\end{array}$} \\
\hline ENG & $\begin{array}{c}0.025 \\
(0.704)\end{array}$ & \\
\hline
\end{tabular}




\begin{tabular}{|c|c|c|}
\hline & Model 1 (Baseline model) & Model 2 \\
\hline AFR & $\begin{array}{c}0.041 \\
(0.099)\end{array}$ & \\
\hline MATHS & $\begin{array}{l}-0.064 \\
(0.231)\end{array}$ & \\
\hline $\mathrm{AP}$ & $\begin{array}{c}0.062 \\
(0.548) \\
\end{array}$ & \\
\hline NBT-AL & $\begin{array}{c}0.035 \\
(0.544)\end{array}$ & \\
\hline NBT-ML & $\begin{array}{c}-0.042 \\
(0.562) \\
\end{array}$ & \\
\hline CAPP & $\begin{array}{l}0.082^{*} \\
(0.000)\end{array}$ & \\
\hline ADJUSTED R² & 0.271 & \\
\hline Std. Error of Estimation & 6.035 & \\
\hline F-statistic & 6.040 & \\
\hline ANOVA Sig. & $0.000^{*}$ & \\
\hline \multicolumn{3}{|c|}{2016} \\
\hline Constant & $\begin{array}{l}18.287^{*} \\
(0.049)\end{array}$ & $\begin{array}{l}36.647^{*} \\
(0.000)\end{array}$ \\
\hline ENG & $\begin{array}{l}-0.094 \\
(0.293)\end{array}$ & \\
\hline AFR & $\begin{array}{c}0.066 \\
(0.247) \\
\end{array}$ & \\
\hline MATHS & $\begin{array}{c}0.106 \\
(0.423)\end{array}$ & \\
\hline AP & $\begin{array}{c}0.398 \\
(0.293)\end{array}$ & \\
\hline NBT-AL & $\begin{array}{c}0.176 \\
(0.233)\end{array}$ & \\
\hline NBT-ML & $\begin{array}{l}-0.286 \\
(0.134) \\
\end{array}$ & \\
\hline FACS1 & $\begin{array}{c}0.062 \\
(0.549)\end{array}$ & \\
\hline FACS2 & $\begin{array}{c}0.045 \\
(0.658)\end{array}$ & $\begin{array}{c}0.179^{*} \\
\left(0.000^{*}\right)\end{array}$ \\
\hline CAPP & $\begin{array}{c}0.091 \\
(0.186) \\
\end{array}$ & \\
\hline ADJUSTED R ${ }^{2}$ & 0.141 & 0.115 \\
\hline Std. Error of Estimation & 17.405 & 17.666 \\
\hline F-statistic & 3.149 & 16.313 \\
\hline ANOVA Sig. & 0.002 & $0.000^{*}$ \\
\hline \multicolumn{3}{|c|}{2017} \\
\hline Constant & $\begin{array}{l}17.049^{*} \\
(0.005)\end{array}$ & $\begin{array}{l}39.664^{*} \\
(0.000)\end{array}$ \\
\hline ENG & $\begin{array}{l}0.319^{*} \\
(0.024)\end{array}$ & \\
\hline AFR & $\begin{array}{c}0.029 \\
(0.441)\end{array}$ & \\
\hline MATHS & $\begin{array}{l}-0.135 \\
(0.260)\end{array}$ & \\
\hline $\mathrm{AP}$ & $\begin{array}{c}0.086 \\
(0.774)\end{array}$ & \\
\hline NBT-AL & $\begin{array}{l}-0.214^{*} \\
(0.012) \\
\end{array}$ & \\
\hline NBT-ML & $\begin{array}{l}0.259^{*} \\
(0.011)\end{array}$ & \\
\hline FACS1 & $\begin{array}{l}-0.058 \\
(0.304) \\
\end{array}$ & \\
\hline FACS2 & $\begin{array}{c}0.039 \\
(0.543)\end{array}$ & $\begin{array}{c}0.110^{*} \\
(0.006)\end{array}$ \\
\hline CAPP & $\begin{array}{l}0.167^{*} \\
(0.032)\end{array}$ & \\
\hline
\end{tabular}




\begin{tabular}{|c|c|c|}
\hline & Model 1 (Baseline model) & Model 2 \\
\hline ADJUSTED R² & 0.168 & 0.045 \\
\hline Std. Error of Estimation & 13.535 & 14.500 \\
\hline F-statistic & 4.273 & 7.871 \\
\hline ANOVA Sig. & $0.000^{*}$ & $0.006^{*}$ \\
\hline \multicolumn{3}{|c|}{2018} \\
\hline Constant & $\begin{array}{l}40.109^{*} \\
(0.000)\end{array}$ & $\begin{array}{l}49.603^{*} \\
(0.000) \\
\end{array}$ \\
\hline ENG & $\begin{array}{c}0.177 \\
(0.154)\end{array}$ & \\
\hline AFR & $\begin{array}{c}-0.003 \\
(0.953) \\
\end{array}$ & \\
\hline MATHS & $\begin{array}{l}-0.047 \\
(0.684) \\
\end{array}$ & \\
\hline $\mathrm{AP}$ & $\begin{array}{c}-0.153 \\
(0.423)\end{array}$ & \\
\hline NBT-AL & $\begin{array}{l}0.233^{*} \\
(0.024)\end{array}$ & \\
\hline NBT-ML & $\begin{array}{l}-0.146 \\
(0.184)\end{array}$ & \\
\hline FACS1 & $\begin{array}{c}0.086 \\
(0.080) \\
\end{array}$ & \\
\hline FACS2 & $\begin{array}{l}-0.156^{*} \\
(0.000)\end{array}$ & $\begin{array}{l}-0.118^{*} \\
(0.006)\end{array}$ \\
\hline CAPP & $\begin{array}{l}-0.037 \\
(0.534)\end{array}$ & \\
\hline ADJUSTED R² & 0.176 & 0.075 \\
\hline Std. Error of Estimation & 10.845 & 11.487 \\
\hline F-statistic & 3.065 & 8.100 \\
\hline ANOVA Sig. & $0.003^{*}$ & $0.006^{*}$ \\
\hline
\end{tabular}

*Statistically significant at the $1 \%$ and $5 \%$ levels

\section{Second-year modules}

Table 5 presents the results of the five regression models for the second academic year for the 2015 to 2018 cohorts. For 2015, Model 1 (baseline model) indicates a significant relationship between PGAUD and MANAF only. None of the other second-year variables was statistically significant for PGAUD in the baseline model.

Model 2 indicates that there is a significant non-linear relationship between MANAC and PGAUD for the 2015 cohort. Although this negative relationship exits for the other cohorts as well, it is not statistically significant. MANAF seems to be statistically significant for the 2015, 2017 and 2018 cohorts. There is also a non-linear relationship between AUD2 and PGAUD, which is significant in 2015 and 2018. This non-linear relationship corresponds to literature stating that previous knowledge of a module is a strong indicator of future academic success (Alyahyan and Düştegör 2020; Onay and Benligiray 2018; Swart and Becker 2014). However, none of the second-year variables in model 2 is significant for the 2016 cohort. Model 2 can be used to explain 42 per cent of the success of the 2015 cohort (Adjusted $R^{2}-0.416$ ). 
Table 5: Regression analysis, second-year modules

\begin{tabular}{|c|c|c|c|c|c|}
\hline & $\begin{array}{c}\text { Model 1 } \\
\text { (Baseline model) }\end{array}$ & Model 2 & Model 3 & Model 4 & Model 5 \\
\hline \multicolumn{6}{|c|}{2015} \\
\hline Constant & $\begin{array}{l}47.709^{*} \\
(0.000)\end{array}$ & $\begin{array}{l}47.713^{*} \\
(0.000)\end{array}$ & $\begin{array}{l}47.301^{*} \\
(0.000)\end{array}$ & $\begin{array}{l}47.862^{*} \\
(0.000)\end{array}$ & $\begin{array}{l}48.348^{*} \\
(0.000)\end{array}$ \\
\hline FACS3 & $\begin{array}{c}0.049 \\
(0.496)\end{array}$ & & $\begin{array}{l}-0.238^{*} \\
(0.049)\end{array}$ & $\begin{array}{l}0.106^{*} \\
(0.000)\end{array}$ & \\
\hline FACS3 $^{2}$ & & & $\begin{array}{c}0.002 \\
(0.496)\end{array}$ & & \\
\hline MANAC & $\begin{array}{l}-0.077 \\
(0.133)\end{array}$ & $\begin{array}{l}-0.301^{*} \\
(0.012)\end{array}$ & & & \\
\hline MANAC ${ }^{2}$ & & $\begin{array}{l}0.003^{*} \\
(0.017)\end{array}$ & & & \\
\hline BUSE & $\begin{array}{c}0.108 \\
(0.109)\end{array}$ & & & & \\
\hline TAX & $\begin{array}{c}0.051 \\
(0.344)\end{array}$ & & & & \\
\hline MANAF & $\begin{array}{l}0.094^{*} \\
(0.024)\end{array}$ & $\begin{array}{l}0.188^{*} \\
(0.001)\end{array}$ & $\begin{array}{l}0.076^{*} \\
(0.021)\end{array}$ & & \\
\hline AUD2 & $\begin{array}{l}-0.054 \\
(0.322)\end{array}$ & $\begin{array}{l}-0.346^{*} \\
(0.005)\end{array}$ & & & $\begin{array}{l}-0.347 \\
(0.009)\end{array}$ \\
\hline AUD2 $^{2}$ & & $\begin{array}{l}0.002^{*} \\
(0.002)\end{array}$ & & & $\begin{array}{l}0.006^{*} \\
(0.001)\end{array}$ \\
\hline CAPP & & $\begin{array}{c}0.006 \\
(0.900) \\
\end{array}$ & & & \\
\hline ADJUSTED R ${ }^{2}$ & 0.320 & 0.416 & 0.352 & 0.279 & 0.304 \\
\hline $\begin{array}{l}\text { Std. Error of } \\
\text { Estimation }\end{array}$ & 5.830 & 5.402 & 5.692 & 6.035 & 5.898 \\
\hline F-statistic & 8.437 & 14.526 & 13.887 & 36.303 & 21.714 \\
\hline ANOVA Sig. & $0.000^{*}$ & $0.000^{*}$ & $0.000^{*}$ & $0.000^{*}$ & $0.000^{*}$ \\
\hline \multicolumn{6}{|c|}{2016} \\
\hline Constant & $\begin{array}{l}33.368^{*} \\
(0.000)\end{array}$ & $\begin{array}{c}34.639^{*} \\
(0.000)\end{array}$ & $\begin{array}{c}31.447^{*} \\
(0.000)\end{array}$ & $\begin{array}{c}32.694^{*} \\
(0.000)\end{array}$ & $\begin{array}{l}33.230^{*} \\
(0.000)\end{array}$ \\
\hline FACS3 & $\begin{array}{c}0.174 \\
(0.091)\end{array}$ & & $\begin{array}{c}0.047 \\
(0.843)\end{array}$ & $\begin{array}{l}0.234^{*} \\
(0.000)\end{array}$ & \\
\hline FACS3 $^{2}$ & & & $\begin{array}{c}0.002 \\
(0.496)\end{array}$ & & \\
\hline MANAC & $\begin{array}{l}-0.125 \\
(0.266)\end{array}$ & $\begin{array}{l}-0.461 \\
(0.082)\end{array}$ & & & \\
\hline MANAC $^{2}$ & & $\begin{array}{c}0.004 \\
(0.168) \\
\end{array}$ & & & \\
\hline BUSE & $\begin{array}{c}0.051 \\
(0.564)\end{array}$ & & & & \\
\hline TAX & $\begin{array}{l}-0.014 \\
(0.806)\end{array}$ & & & & \\
\hline MANAF & $\begin{array}{c}0.150 \\
(0.232)\end{array}$ & $\begin{array}{c}0.203 \\
(0.082)\end{array}$ & $\begin{array}{c}0.071 \\
(0.509)\end{array}$ & & \\
\hline AUD2 & $\begin{array}{c}0.002 \\
(0.984)\end{array}$ & $\begin{array}{c}0.190 \\
(0.549)\end{array}$ & & & $\begin{array}{c}0.088 \\
(0.758)\end{array}$ \\
\hline AUD2 $^{2}$ & & $\begin{array}{l}-0.001 \\
(0.902)\end{array}$ & & & $\begin{array}{c}0.002 \\
(0.667)\end{array}$ \\
\hline CAPP & & & $\begin{array}{l}-0.009 \\
(0.933)\end{array}$ & & \\
\hline ADJUSTED R² & 0.139 & 0.129 & 0.144 & 0.164 & 0.111 \\
\hline $\begin{array}{l}\text { Std. Error of } \\
\text { Estimation }\end{array}$ & 17.420 & 17.528 & 17.370 & 17.242 & 17.706 \\
\hline F-statistic & 4.183 & 4.485 & 5.976 & 22.945 & 8.360 \\
\hline ANOVA Sig. & $0.001^{*}$ & $0.001^{*}$ & $0.000^{*}$ & $0.000^{*}$ & $0.000^{*}$ \\
\hline \multicolumn{6}{|c|}{2017} \\
\hline Constant & $\begin{array}{l}25.481^{*} \\
(0.000)\end{array}$ & $\begin{array}{l}29.084^{*} \\
(0.000)\end{array}$ & $\begin{array}{l}29.571^{*} \\
(0.000)\end{array}$ & $\begin{array}{l}38.118^{*} \\
(0.000)\end{array}$ & $\begin{array}{l}40.186^{*} \\
(0.000)\end{array}$ \\
\hline
\end{tabular}


Crous and Goodchild Predictors of academic success in Postgraduate Auditing in the Chartered Accountancy Programme

\begin{tabular}{|c|c|c|c|c|c|}
\hline & $\begin{array}{c}\text { Model } 1 \\
\text { (Baseline model) }\end{array}$ & Model 2 & Model 3 & Model 4 & Model 5 \\
\hline FACS3 & $\begin{array}{c}0.079 \\
(0.462) \\
\end{array}$ & & $\begin{array}{l}-0.386^{*} \\
(0.008)\end{array}$ & $\begin{array}{l}0.148^{*} \\
(0.002)\end{array}$ & \\
\hline FACS3 $^{2}$ & & & $\begin{array}{l}0.006^{*} \\
(0.002)\end{array}$ & & \\
\hline MANAC & $\begin{array}{c}0.072 \\
(0.560)\end{array}$ & $\begin{array}{l}-0.409 \\
(0.095)\end{array}$ & & & \\
\hline MANAC $^{2}$ & & $\begin{array}{c}0.004 \\
(0.072) \\
\end{array}$ & & & \\
\hline BUSE & $\begin{array}{c}0.022 \\
(0.880)\end{array}$ & & & & \\
\hline TAX & $\begin{array}{l}-0.090 \\
(0.098) \\
\end{array}$ & & & & \\
\hline MANAF & $\begin{array}{c}0.221 \\
(0.153) \\
\end{array}$ & $\begin{array}{l}0.343^{*} \\
(0.000) \\
\end{array}$ & $\begin{array}{l}0.473^{*} \\
(0.000)\end{array}$ & & \\
\hline AUD2 & $\begin{array}{l}-0.065 \\
(0.544)\end{array}$ & $\begin{array}{l}-0.089 \\
(0.655)\end{array}$ & & & $\begin{array}{l}-0.258 \\
(0.152) \\
\end{array}$ \\
\hline AUD2 $^{2}$ & & $\begin{array}{c}0.001 \\
(0.648) \\
\end{array}$ & & & $\begin{array}{l}0.005^{\star} \\
(0.027)\end{array}$ \\
\hline CAPP & & & $\begin{array}{l}-0.232^{*} \\
(0.036) \\
\end{array}$ & & \\
\hline ADJUSTED R² & 0.211 & 0.230 & 0.272 & 0.063 & 0.072 \\
\hline $\begin{array}{l}\text { Std. Error of } \\
\text { Estimation }\end{array}$ & 13.182 & 13.200 & 12.660 & 14.410 & 4.292 \\
\hline F-statistic & 7.496 & 9.722 & 14.636 & 9.788 & 6.682 \\
\hline ANOVA Sig. & $0.000^{*}$ & $0.000^{*}$ & $0.000^{*}$ & $0.002^{*}$ & $0.002^{*}$ \\
\hline \multicolumn{6}{|c|}{2018} \\
\hline Constant & $\begin{array}{l}42.355^{*} \\
(0.000) \\
\end{array}$ & $\begin{array}{l}44.922^{*} \\
(0.000) \\
\end{array}$ & $\begin{array}{l}43.700^{*} \\
(0.000)\end{array}$ & $\begin{array}{l}42.565^{*} \\
(0.000)\end{array}$ & $\begin{array}{l}45.909^{*} \\
(0.000)\end{array}$ \\
\hline FACS3 & $\begin{array}{c}0.026 \\
(0.892) \\
\end{array}$ & & $\begin{array}{l}-0.467^{*} \\
(0.011) \\
\end{array}$ & $\begin{array}{l}0.099^{*} \\
(0.033) \\
\end{array}$ & \\
\hline FACS3 $^{2}$ & & & $\begin{array}{l}0.007^{*} \\
(0.002)\end{array}$ & & \\
\hline MANAC & $\begin{array}{l}-0.173 \\
(0.305) \\
\end{array}$ & $\begin{array}{l}-0.351 \\
(0.328) \\
\end{array}$ & & & \\
\hline MANAC $^{2}$ & & $\begin{array}{c}0.002 \\
(0.527) \\
\end{array}$ & & & \\
\hline BUSE & $\begin{array}{c}-0.017 \\
(0.892) \\
\end{array}$ & & & & \\
\hline TAX & $\begin{array}{l}-0.121 \\
(0.496) \\
\end{array}$ & & & & \\
\hline MANAF & $\begin{array}{c}0.230 \\
(0.165)\end{array}$ & $\begin{array}{c}0.260 \\
(0.118)\end{array}$ & $\begin{array}{c}0.023 \\
(0.860)\end{array}$ & & \\
\hline AUD2 & & $\begin{array}{l}-0.399 \\
(0.073) \\
\end{array}$ & & & $\begin{array}{l}-0.451^{*} \\
(0.002) \\
\end{array}$ \\
\hline AUD2 $^{2}$ & $\begin{array}{c}0.018 \\
(0.905)\end{array}$ & $\begin{array}{l}0.005^{\star} \\
(0.030)\end{array}$ & & & $\begin{array}{l}0.006^{*} \\
(0.000)\end{array}$ \\
\hline CAPP & & & $\begin{array}{c}0.031 \\
(0.804)\end{array}$ & & \\
\hline ADJUSTED R ${ }^{2}$ & 0.013 & 0.153 & 0.123 & 0.052 & 0.155 \\
\hline $\begin{array}{l}\text { Std. Error of } \\
\text { Estimation }\end{array}$ & 11.867 & 10.993 & 11.187 & 11.702 & 10.984 \\
\hline F-statistic & 1.194 & 4.149 & 5.054 & 4.670 & 8.957 \\
\hline ANOVA Sig. & 0.318 & $0.002^{*}$ & $0.005^{*}$ & $0.033^{*}$ & $0.000^{*}$ \\
\hline
\end{tabular}

*Statistically significant at the $1 \%$ and $5 \%$ levels.

Model 3 shows a significant non-linear negative relationship between FACS3 and PGAUD for the 2015, 2017 and 2018 cohorts. MANAF shows a significant, positive relationship with PGAUD in 2015 and 2017. For the 2017 cohort, CAPP shows a negative significant relationship 
with PGAUD. However, none of the second-year variables in model 3 is significant for the 2016 cohort. Based on the results, Model 3 can be used to explain 27 per cent of the success of the 2017 cohort for PGAUD (Adjusted $\mathrm{R}^{2}-0.272$ ).

Model 4 shows a significant, positive relationship with PGAUD for all cohorts from 2015 to 2018. Taken as the only predictor of success for PGAUD, it seems that this model is the best suited for all cohorts based on the significance of the relationships. Noteworthy is the fact that the significant predictor of success for Auditing at postgraduate level is financial accounting and not Auditing at undergraduate level. This support general literature that undergraduate performance is important for postgraduate performance, but refute the idea that the experience or background is in the same discipline like accounting (Alyahyan and Düştegör 2020; Duff 2007; Onay and Benligiray 2018; Steenkamp 2014; Swart and Becker 2014). Nevertheless, the Adjusted $\mathrm{R}^{2}$ of each cohort indicates that this model can only explain between 5 per cent (2018 $-0.052)$ and 28 per cent $(2015-0.279)$ of students' success in PGAUD.

Model 5 shows a significant negative non-linear relationship between AUD2 and PGAUD for the 2016, 2017 and 2018 cohorts. Based on the Adjusted $\mathrm{R}^{2}$ of this model on the cohort, this model seems best suited for explaining 30 per cent of the success for the 2015 cohort $(0.304)$.

Based on the results, it is clear that Model 4 is the most successful in explaining student success. This indicates that in order to predict student success in the PGAUD module, only FACS3 should be taken into account at the second-year academic level.

\section{Third-year modules}

Table 6 presents the results of the five regression models for the third academic year for the 2014 to 2018 cohorts. In the baseline model, FACS4 shows a significant negative relationship for the 2014 cohort only. For the 2015-2018 cohorts, FACS4 shows a positive, but insignificant relationship to PGAUD. The baseline model further indicates a significant positive relationship with AUD3 for the 2014 cohort and a significant negative relationship for the 2017 cohort. The positive relationships between AUD3 and PGAUD supports the findings in literature that previous knowledge of a subjects is an indicator of academic success in further studies (Alyahyan and Düştegör 2020; Onay and Benligiray 2018; Swart and Becker 2014). Although there is a positive relationship between PGAUD and AUD3 in the three remaining cohorts, this relationship is not significant refuting previous studies that showed a significant relationship between academic success and previous knowledge. For the 2015 cohort, TAX3 and MANAAF shows a significant relationship with PGAUD. The relationship with TAX3 is a positive relationship, whereas MANAAF shows a negative relationship. The baseline model, therefore, is not a good fit for determining academic success in the PGAUD module. 
Model 2 in Table 6 reveals a non-linear relationship between FACS4 and PGAUD. This is similar to the relationship between non-audit second year modules and PGAUD. This relationship is a significant negative relationship for all but the 2016 cohort. AUD3 shows a significant positive relationship for the 2015 cohort. Although this relationship remains positive for the 2016 to 2018 cohort groups as well, the relationship is not significant. With an adjusted $\mathrm{R}^{2}$ value of 0.275 , this model seems to be the best fit for explaining success for the 2014 PGAUD cohort.

Model 3 shows a possible non-linear relationship between MANAAF and PGAUD. This significant negative relationship is evident for cohorts 2014, 2015, 2017 and 2018. Although the negative relationship is also evident in 2016, it is not significant. TAX3 shows a significant positive relationship to PGAUD for the 2015 and 2018 cohorts. Based on the adjusted $\mathrm{R}^{2}$ value (0.480), this model is best suited to explain the success of the 2015 cohort.

Table 6: Regression analysis, third-year modules

\begin{tabular}{|c|c|c|c|c|c|}
\hline & $\begin{array}{c}\text { Model 1 } \\
\text { (Baseline model) }\end{array}$ & Model 2 & Model 3 & Model 4 & Model 5 \\
\hline \multicolumn{6}{|c|}{2014} \\
\hline Constant & $\begin{array}{l}41.893^{*} \\
(0.000)\end{array}$ & $\begin{array}{l}43.030^{*} \\
(0.000)\end{array}$ & $\begin{array}{l}42.279^{*} \\
(0.000)\end{array}$ & $\begin{array}{l}42.202^{*} \\
(0.000)\end{array}$ & $\begin{array}{l}41.228^{*} \\
(0.000)\end{array}$ \\
\hline FACS4 & $\begin{array}{l}-0.632^{*} \\
(0.003)\end{array}$ & $\begin{array}{l}-1.835^{*} \\
(0.000)\end{array}$ & & $\begin{array}{c}0.077 \\
(0.083)\end{array}$ & \\
\hline FACS4 $^{2}$ & & $\begin{array}{l}0.018^{*} \\
(0.000)\end{array}$ & & & \\
\hline AUD3 & $\begin{array}{l}0.486^{*} \\
(0.017)\end{array}$ & $\begin{array}{l}0.778^{*} \\
(0.000)\end{array}$ & & & \\
\hline \multicolumn{6}{|l|}{ AUD3 $^{2}$} \\
\hline TAX3 & $\begin{array}{l}-0.024 \\
(0.934)\end{array}$ & & $\begin{array}{c}0.503 \\
(0.058)\end{array}$ & & \\
\hline TAX3 $^{2}$ & $(0.234)$ & & & & \\
\hline MANAAF & $(0.332)$ & & $\begin{array}{l}-1.499^{*} \\
(0.000)\end{array}$ & & $\begin{array}{l}0.093^{*} \\
(0.015)\end{array}$ \\
\hline MANAAF $^{2}$ & & & $\begin{array}{l}0.015^{\star} \\
(0.000)\end{array}$ & & \\
\hline ADJUSTED R² & 0.124 & 0.275 & 0.177 & 0.015 & 0.037 \\
\hline $\begin{array}{l}\text { Std. Error of } \\
\text { Estimation }\end{array}$ & 14.889 & 13.546 & 14.430 & 15.782 & 15.906 \\
\hline F-statistic & 5.655 & 17.655 & 10.450 & 3.058 & 6.040 \\
\hline ANOVA Sig. & $0.000^{*}$ & $0.000^{*}$ & $0.000^{*}$ & 0.083 & $0.015^{*}$ \\
\hline \multicolumn{6}{|c|}{2015} \\
\hline Constant & $\begin{array}{l}48.353^{*} \\
(0.000)\end{array}$ & $\begin{array}{l}49.424^{*} \\
(0.000)\end{array}$ & $\begin{array}{l}49.887^{*} \\
(0.000)\end{array}$ & $\begin{array}{l}48.072^{*} \\
(0.000) \\
\end{array}$ & $\begin{array}{l}48.454^{*} \\
(0.000) \\
\end{array}$ \\
\hline FACS4 & $\begin{array}{c}0.020 \\
(0.889)\end{array}$ & $\begin{array}{l}-0.695^{*} \\
(0.000)\end{array}$ & & $\begin{array}{l}0.084^{*} \\
(0.001)\end{array}$ & \\
\hline FACS4 $^{2}$ & & $\begin{array}{l}0.009^{*} \\
(0.000)\end{array}$ & & & \\
\hline AUD3 & $\begin{array}{l}-0.055 \\
(0.663) \\
\end{array}$ & $\begin{array}{l}0.219^{*} \\
(0.012) \\
\end{array}$ & & & \\
\hline \multicolumn{6}{|l|}{ AUD3 $^{2}$} \\
\hline TAX3 & $\begin{array}{l}0.393^{*} \\
(0.021)\end{array}$ & & $\begin{array}{l}0.447^{*} \\
(0.000)\end{array}$ & & \\
\hline
\end{tabular}


Crous and Goodchild Predictors of academic success in Postgraduate Auditing in the Chartered Accountancy Programme

\begin{tabular}{|c|c|c|c|c|c|}
\hline & $\begin{array}{c}\text { Model } 1 \\
\text { (Baseline model) }\end{array}$ & Model 2 & Model 3 & Model 4 & Model 5 \\
\hline \multicolumn{6}{|l|}{ TAX3 $^{2}$} \\
\hline MANAAF & $\begin{array}{l}-0.260^{*} \\
(0.033)\end{array}$ & & $\begin{array}{l}-0.983^{*} \\
(0.000)\end{array}$ & & $\begin{array}{l}0.066^{*} \\
(0.005)\end{array}$ \\
\hline MANAAF $^{2}$ & & & $\begin{array}{l}0.009^{*} \\
(0.000)\end{array}$ & & \\
\hline ADJUSTED R² & 0.146 & 0.389 & 0.480 & 0.096 & 0.071 \\
\hline $\begin{array}{l}\text { Std. Error of } \\
\text { Estimation }\end{array}$ & 6.530 & 5.523 & 5.099 & 6.720 & 15.609 \\
\hline F-statistic & 5.072 & 21.183 & 30.180 & 11.098 & 8.264 \\
\hline ANOVA Sig. & $0.001^{*}$ & $0.000^{*}$ & $0.000^{*}$ & $0.001^{*}$ & $0.005^{*}$ \\
\hline \multicolumn{6}{|c|}{2016} \\
\hline Constant & $\begin{array}{l}32.760^{*} \\
(0.000)\end{array}$ & $\begin{array}{l}33.321^{*} \\
(0.000)\end{array}$ & $\begin{array}{l}33.844^{*} \\
(0.000)\end{array}$ & $\begin{array}{l}32.645^{*} \\
(0.000)\end{array}$ & $\begin{array}{l}33.170^{*} \\
(0.000)\end{array}$ \\
\hline FACS4 & $\begin{array}{c}0.004 \\
(0.991) \\
\end{array}$ & $\begin{array}{l}-0.060 \\
(0.877) \\
\end{array}$ & & $\begin{array}{l}0.255^{*} \\
(0.000) \\
\end{array}$ & \\
\hline FACS4 $^{2}$ & & $\begin{array}{c}0.004 \\
(0.308) \\
\end{array}$ & & & \\
\hline AUD3 & $\begin{array}{l}-0.023 \\
(0.915) \\
\end{array}$ & $\begin{array}{c}0.063 \\
(0.777) \\
\end{array}$ & & & \\
\hline \multicolumn{6}{|l|}{$\mathrm{AUD3}^{2}$} \\
\hline TAX3 & $\begin{array}{c}0.004 \\
(0.991) \\
\end{array}$ & & $\begin{array}{c}0.334 \\
(0.326) \\
\end{array}$ & & \\
\hline \multicolumn{6}{|l|}{ TAX3 $^{2}$} \\
\hline MANAAF & $\begin{array}{l}-0.074 \\
(0.825) \\
\end{array}$ & & $\begin{array}{l}-0.451 \\
(0.335) \\
\end{array}$ & & $\begin{array}{l}0.234^{*} \\
(0.000) \\
\end{array}$ \\
\hline MANAAF $^{2}$ & & & $\begin{array}{c}0.005 \\
(0.142) \\
\end{array}$ & & \\
\hline ADJUSTED R ${ }^{2}$ & 0.127 & 0.142 & 0.139 & 0.149 & 0.135 \\
\hline $\begin{array}{l}\text { Std. Error of } \\
\text { Estimation }\end{array}$ & 17.540 & 17.391 & 17.482 & 17.327 & 17.467 \\
\hline F-statistic & 5.306 & 7.520 & 7.328 & 12.755 & 19.377 \\
\hline ANOVA Sig. & $0.001^{*}$ & $0.000^{*}$ & $0.000^{*}$ & $0.000^{*}$ & $0.000^{*}$ \\
\hline \multicolumn{6}{|c|}{2017} \\
\hline Constant & $\begin{array}{l}37.190^{*} \\
(0.000) \\
\end{array}$ & $\begin{array}{l}40.978^{*} \\
(0.000) \\
\end{array}$ & $\begin{array}{l}41.235^{*} \\
(0.000) \\
\end{array}$ & $\begin{array}{l}37.339^{*} \\
(0.000) \\
\end{array}$ & $\begin{array}{l}36.646^{*} \\
(0.000) \\
\end{array}$ \\
\hline FACS4 & $\begin{array}{c}0.145 \\
(0.451) \\
\end{array}$ & $\begin{array}{l}-0.446 \\
(0.065)\end{array}$ & & $\begin{array}{l}0.173^{*} \\
(0.000) \\
\end{array}$ & \\
\hline FACS4 $^{2}$ & & $\begin{array}{l}0.010^{*} \\
(0.000)\end{array}$ & & & \\
\hline AUD3 & $\begin{array}{l}-0.430^{*} \\
(0.047) \\
\end{array}$ & $\begin{array}{l}-0.048 \\
(0.755) \\
\end{array}$ & & & \\
\hline \multicolumn{6}{|l|}{ AUD3 $^{2}$} \\
\hline TAX3 & $\begin{array}{c}0.091 \\
(0.715) \\
\end{array}$ & & $\begin{array}{c}0.153 \\
(0.376) \\
\end{array}$ & & \\
\hline \multicolumn{6}{|l|}{$\mathrm{TAX3}^{2}$} \\
\hline MANAAF & $\begin{array}{l}0.362^{*} \\
(0.049) \\
\end{array}$ & & $\begin{array}{l}-0.668^{*} \\
(0.011) \\
\end{array}$ & & $\begin{array}{l}0.177^{*} \\
(0.000)\end{array}$ \\
\hline MANAAF $^{2}$ & & & $\begin{array}{l}0.009^{*} \\
(0.000) \\
\end{array}$ & & \\
\hline ADJUSTED R² & 0.101 & 0.182 & 0.216 & 0.075 & 0.089 \\
\hline $\begin{array}{l}\text { Std. Error of } \\
\text { Estimation }\end{array}$ & 14.068 & 13.420 & 13.135 & 14.274 & 14.159 \\
\hline F-statistic & 5.104 & 11.828 & 14.438 & 12.755 & 15.322 \\
\hline ANOVA Sig. & $0.001^{*}$ & $0.000^{*}$ & $0.000^{*}$ & $0.000^{*}$ & $0.000^{*}$ \\
\hline \multicolumn{6}{|c|}{2018} \\
\hline Constant & $\begin{array}{l}43.038^{*} \\
(0.000) \\
\end{array}$ & $\begin{array}{l}45.277^{*} \\
(0.000)\end{array}$ & $\begin{array}{l}45.186^{*} \\
(0.000) \\
\end{array}$ & $\begin{array}{l}42.491^{*} \\
(0.000)\end{array}$ & $\begin{array}{l}43.160^{*} \\
(0.000)\end{array}$ \\
\hline FACS4 & $\begin{array}{c}0.352 \\
(0.209) \\
\end{array}$ & $\begin{array}{l}-1.069^{*} \\
(0.003) \\
\end{array}$ & & $\begin{array}{l}0.112^{*} \\
(0.026)\end{array}$ & \\
\hline
\end{tabular}




\begin{tabular}{|c|c|c|c|c|c|}
\hline & $\begin{array}{c}\text { Model 1 } \\
\text { (Baseline model) }\end{array}$ & Model 2 & Model 3 & Model 4 & Model 5 \\
\hline FACS4 $^{2}$ & & $\begin{array}{l}0.013^{*} \\
(0.000)\end{array}$ & & & \\
\hline AUD3 & $\begin{array}{l}-0.038 \\
(0.880)\end{array}$ & $\begin{array}{c}0.337 \\
(0.106)\end{array}$ & & & \\
\hline \multicolumn{6}{|l|}{ AUD3 $^{2}$} \\
\hline TAX3 & $\begin{array}{c}0.009 \\
(0.975)\end{array}$ & & $\begin{array}{l}0.473^{*} \\
(0.012)\end{array}$ & & \\
\hline \multicolumn{6}{|l|}{ TAX3 $^{2}$} \\
\hline MANAAF & $\begin{array}{l}-0.213 \\
(0.367)\end{array}$ & & $\begin{array}{l}-1.201^{*} \\
(0.000)\end{array}$ & & $\begin{array}{c}0.093 \\
(0.061)\end{array}$ \\
\hline MANAAF $^{2}$ & & & $\begin{array}{l}0.012^{*} \\
(0.000)\end{array}$ & & \\
\hline ADJUSTED R ${ }^{2}$ & 0.026 & 0.216 & 0.205 & 0.045 & 0.029 \\
\hline $\begin{array}{l}\text { Std. Error of } \\
\text { Estimation }\end{array}$ & 11.791 & 10.756 & 10.649 & 11.674 & 11.772 \\
\hline F-statistic & 1.578 & 9.002 & 8.499 & 5.107 & 3.594 \\
\hline ANOVA Sig. & 0.188 & $0.000^{*}$ & $0.000^{*}$ & $0.000^{*}$ & $0.000^{*}$ \\
\hline
\end{tabular}

Model 4 includes only FACS4 as a predictor for success without taking any non-linear relationship into account. Based on the results, FACS4 has a significant positive relationship with PGAUD for the 2015 to 2018 cohorts. The adjusted $\mathrm{R}^{2}$ values differ from 0.045 to 0.149 and so indicate that the use of only FACS4 can explain between 5 per cent and 15 per cent of the results in PGAUD. This indicates that there may be other contributing non-academic factors that influence success in the third academic year.

Model 4 includes only MANAAF as a predictor of success, without taking any non-linear relationship into account. Based on the results, MANAAF has a significant, positive relationship with PGAUD for the 2014 to 2017 cohorts. The adjusted $\mathrm{R}^{2}$ values differ from 0.037 to 0.135 , which indicates that the use of only MANAAF can explain between 4 per cent and 14 per cent of the results in PGAUD. This indicates that there may be other contributing non-academic factors that influence success in the third academic year.

Considering the adjusted $\mathrm{R}^{2}$ for model 4 and 5, model 4 seems to be most applicable to all cohorts, as this module produces slightly higher $\mathrm{R}^{2}$ results. When combining the two variables into one module, the results indicate that neither of the variables shows significant relationships for any of the cohorts. The possibility of combining the two into an additional model was therefore rejected.

Based on the premise that model 4 is used as the prediction model for the third academic year, hypothesis 3 is thus accepted to hold and that there are significant positive relationships between undergraduate modules in the third year and PGAUD.

\section{CONCLUSIONS}

Even though the intention is not to generalize beyond the scope of the article itself, the findings 
may provide valuable information to academics in the accountancy programme. The overall aim of this article was to identify possible academic indicators that can predict success of postgraduate students in auditing at a specific university. Multiple-regression analyses were used to identify significant relationships between auditing at postgraduate level and first-, second- and third-year modules. Different models were developed and tested to identify the best predictors of success in each academic year for the postgraduate cohorts of 2014 to 2018.

Contrary to studies performed by Steenkamp (2014), Swart and Becker (2014) and Oosthuizen and Eiselen (2012), this study concludes that neither grade 12 maths and language proficiencies, nor NBT results or AP scores are predictors of success for postgraduate audit studies - which leads to the rejection of the first two Hypotheses of the study.

We furthermore found that there is no single prediction model that can explain or predict the success of postgraduate auditing, as the results and significant variances differ from cohort to cohort for all academic years. The relatively low adjusted $\mathrm{R}^{2}$ of 12 per cent in the first academic year further indicates that there may be other factors in the first academic year that influence the performance in postgraduate studies. These factors may include the effect of supportive courses presented in the first academic year, as well as non-academic factors such as the gender and age of the students as well as the lecturer in the specific module.

Although the undergraduate auditing modules (AUD2 and AUD3) are prerequisites for PGAUD and considered to be important for success in the postgraduate module, the said modules were not identified as success indicators and contradicts the literature that indicate that previous knowledge of a discipline can predict success in later academic endeavours (Duff 2007; Steenkamp 2014; Sulaiman and Mohezar 2006). Possible predictors of academic success in the second and third academic years are modules that are not directly related to auditing at postgraduate level; namely, Financial Accounting in the second (FACS3) and third (FACS4) academic years and Managerial Accounting and Finance (MANAAF) in the third academic year. This may be explained by the distribution of skills development in the undergraduate modules into the postgraduate module, but causality of the relationships was not identified in this study and warrants further research. Based on the mixed results in terms of significance and direction of relationships, Hypothesis 3 was rejected for the first academic year as well as for MANAAF in the third academic year. However, the analysis indicated a significant, positive relationship in the second academic year for model 4 and in model 5 of the third academic year related to FACS4.

A limitation of this study is that it is based only on one university and that the results are consequently not generalizable to all South African circumstances. Furthermore, the study included only academic success predictors and further research is therefore required to identify 
possible non-academic indicators. Additional research into the skills developed in the specific undergraduate modules that show significant relationships with postgraduate success may clarify the contradictory results of this study in respect of previous research.

\section{NOTE}

1. The Computer Applications module at this HEI is a sub-module of Auditing. It includes computerized business controls and is not seen as a supportive course, but as part of the auditing discipline. The module is also offered by the Accountancy department and its staff.

\section{REFERENCE LIST}

Alyahyan, E. and D. Düştegör. 2020. "Predicting Academic Success in Higher Education: Literature Review and Best Practices." International Journal of Educational Technology in Higher Education 17(3): 1-21.

Amnesty International. 2020. Education in South Africa: Broken and Unequal. London, England.

Baard, R. S., L. P. Steenkamp, B. L. Frick, and M. Kidd. 2010. "Factors Influencing Success in First Year Accounting at a South African University." South African Journal of Accounting Research 23(1): $129-47$.

Barnes, H., D. Dzansi, and M. Viljoen. 2009. "Researching the First Year Accounting Problem: Factors Influencing Success or Failure at a South African Higher Education Institution." Journal for New Generation Sciences 17(2): 36-58.

Boland, R. J., S. K. Sharma, and P. S. Afonso. 2008. "Designing Management Controls in Hybrid Organisations: The Role of Path Creation and Mophogenesis." Accounting Organizations and Society 33(7-8): 899-914.

Botha, A. E., C. Mccrindle, and J. H. Owen. 2003. "Mathematics at Matriculation Level as an Indicator of Success or Failure in the 1st Year of the Veterinary Nursing Diploma at the Faculty of Veterinary Science." Journal of the South African Veterinary Association 74(4): 132-34.

Bruwer, A. and J. M. Ontong. 2020. "Early Assessment as a Predictor of Academic Performance: An Analysis of the Interaction Between Early Assessment and Academic Performance by First-Year Accounting Students at a South African University." South African Journal of Higher Education 34(4): 11-26.

Buckless, F. and K. Krawczyk. 2016. "The Relation of Student Engagement and Other Admission Metrics to Master of Accounting Student Performance." Accounting Education 25(6): 519-533.

Cai, Y. 2015. "The Use of Institutional Theory in Higher Education Research.” In Theory and Method in Higher Education Research III, ed. Jeroen Huisman and Malcolm Tight, 1-25. Emerald Group Publishing Limited, Bingley.

De Villiers, C. and E. Venter. 2013. "The Influence of the Accounting Profession on the Academy: A Cautionary Case Study." Accounting, Auditing and Accountability 26(8): 1246-78.

Drennan, L. G. and F. H. Rohde. 2002. "Determinants of Performance in Advanced Undergraduate Management Accounting: An Empirical Investigation." Accounting and Finance 42(1): 27-40.

Du Plessis, L. and D. Gerber. 2012. "Academic Preparedness of Students - an Exploratory Study." The Journal for Transdisciplinary Research in Southern Africa 18(1): 81-94.

Duff, A. 2007. "Understanding the Academic Performance and Progression of First-Year Accounting and Business Economics Undergraduates: The Role of Approaches to Learning and Prior Academic Achievement." Accounting Education 13(4): 409-30.

Editorial Staff. 2017. "South Africa Has One of the Worlds Worst Education Systems." The Economist 21 October. https://www.economist.com/middle-east-and-africa/2017/01/07/south-africa-has-one- 
of-the-worlds-worst-education-systems.

Eiselen, R., J. Strauss and B. Jonck. 2007. “A Basic Mathematical Skills Test as Predictor of Performance at Tertiary Level." South African Journal of Higher Education 21(1): 38-39.

Fraser, W. J. and R. Killen. 2003. "Factors Influencing Academic Success or Failure of First-Year and Senior University Students: Do Education Students and Lecturer's Perceive Things Differently?" South African Journal of Education 23(4): 254-60.

Gammie, E., P. Jones, and Robertson-Millar. 2003. "Accountancy Undergraduate Performance: A Statistical Model." Accounting Education 12(1): 63-78.

HESA see Higher Education South Africa.

Higher Education South Africa. 2006. "Access and Entry Level Benchmarks, the National benchmark tests project". Edited by Hanlie Griesel, Sunnyside, Pretoria.

Huang, S. 2011. "Predictive Modeling and Analysis of Student Academic Performance in an Engineering Dynamic Course." Unpublished PhD. Utah State University.

Jansen, J. 2012. "National Senior Certificate Results Belie Conceptual and Skill Limitations of SchoolLeavers." South African Journal of Science 108(3-4): 09-10.

Jansen, J. and C. de Villiers. 2015. "Determinants of Student Performance in an Accounting Degree Programme." South African Journal of Accounting Research 30(1): 1-28.

Kruger, S. J. 2020. "Accountancy Students' and Lecturers' Perceptions of the Effect of Open-Book Assessment on Writing Examinations." South African Journal of Higher Education 34(1): 158-75.

Lourens, A. and P. J. Smit. 2004. "Retention: Predicting First Year Success." South African Journal for Higher Education 17(2): 169-177.

Matarirano, O., M. Panicker, C. Atoliyah, and Z.Mangisa. 2019. "Factors Impacting Academic Performance of First-Year Accountancy Students at Walter Sisulu University." Africa Education Review 17(1): 8-99.

Maurice, N. K. 2015. "Key Indicators of Student Success at a Tertiary Institution: A Case Study of CTI Education Group's Accounting Programmes." Durban University of Technology.

Monare, M. 2010. "Selfish Power Struggles Standing Black Pupils.” Pretoria News 10 January.

Muller, A. 2013. "The Predictive Value of Grade 12 and University Access Tests Results for Success in Higher Education." Stellenbosch University.

Muller, H. and P. Prinsloo. 2007. "Validate the Profile of the Successful First Year Accounting Student." Meditari Accountancy Research 15(1): 19-33.

Myers, S. 2016. "An Analysis of How Students Construct Knowledge in a Course with a Hierarchical Knowledge Structure.” South African Journal of Accounting Research 31(3): 193-211.

Onay, A. and S. Benligiray. 2018. "Internal Factors Affecting Student Performance in Accounting Courses at a Vocational School." Sumerianz Journal of Economics and Finance 1(3): 82-90.

Ontong, J. M., T. de Waal, and W. Wentzel. 2020. "How Accounting Students Within the Thuthuka Bursary Fund Perceive Academic Support Offered at One South African University." South African Journal of Higher Education 34(1): 197-212.

Oosthuizen, A. and R. Eiselen. 2012. "Factors Associated with Success in First-Year Accounting after the Implementation of the National Senior Certificate." Acta Academia 44(3): 156-74.

Papageorgiou, E. 2017. “Accounting Student's Profile vs Academic Performance: A Five Year Analysis." South African Journal of Higher Education 31(3): 209-29.

Papageorgiou, E. and C. W. Callaghan. 2018. "Personality and Adjustment in South African Higher Education Accounting Studies." South African Journal of Accounting Research 32(2-3): 189-204.

Papageorgiou, E. and R. Carpenter. 2019. "Prior Accounting Knowledge of First-year Students at Two South African Universities: Contributing Factor to Academic Performance or Not?" South African Journal of Accounting Research 33(6): 249-264. 
Rankin, N., V. Schoer, and C. Sebastiao. 2012. "Predictors of Academic Performance: National Senior Certificate versus National Benchmark Test." South African Journal of Higher Education 26(3): 564-585.

Rossouw, M. 2018. "Language of Instruction and Effect on the Performance of Accounting Students." South African Journal of Higher Education 32(2): 258-272.

Sadler, E. and B. J. Erasmus. 2005. "The Academic Success and Failure of Black Chartered Accounting Graduates in South Africa: A Distance Education Perspective." Meditari Accountancy Research 13(1): 29-50.

SAICA see South African Institute of Chartered Accountants SAICA

South African Institute of Chartered Accountants. 2018. "How to Become a CA(SA)." SAICA. 2018. https://www.saica.co.za/Training/BecomingaCA/tabid/157/language/en-ZA/Default.aspx.

South African Institute of Chartered Accountants. 2019. Media release. Transformation initiatives are paying off says accountancy body. 29 March. https://saicawebprstorage.blob.core.windows.net/ uploads/Examination-docs/Press_release_ITC_Jan_2019b.pdf.

Steenkamp, G. 2014. "How Pre-Admission Characteristics Affect the Performance of CTA Students." Journal of Economic and Financial Sciences 7(2): 283-98.

Sulaiman, A. and S. Mohezar. 2006. "Student Success Factors: Identifying Key Predictors." Journal of Education for Business 81(6): 328-33.

Swart, O. and A. I. Becker. 2014. "Matric Results in Mathematics and Languages: A Predictor of Undergraduate and Post Graduate Success." Progressio 36(1): 157-82.

Taylor, N. 2006. "Schools, Skills and Citizenship." JET Bulletin 15: 2-3.

Terblanche, J. and Y. Waghid. 2020. "A Foucauldian Analysis of the CA Profession in South Africa: Implications for Society." South African Journal of Higher Education 34(1): 1-17.

Ungerer, M. A., I. Becker, M. J. Niewoudt, O. J. Swart, and S. J. Wilcocks. 2013. "The Importance of the Changing Demographic Profile on the Success of Postgraduate Accounting Students." South African Journal of Higher Education 27(6): 1529-1550.

Van der Westhuizen, D. and G. Barlow-Jones. 2015. "High School Mathematics Marks as an Admission Criterion for Entry into Programming Courses at a South African University." The Independent Journal of Teaching and Learning 10(1): 37-50.

Van Zyl, A. 2010. "The Predictive Value of Pre-Entry Attributes for Student Academic Performance in the South African Context." PhD Thesis in Higher Education in the Faculty of Education. University of Johannesburg. Johannesburg.

Visser, H. and D. van Zyl. 2013. "Assessment of Academic Readiness to Achieve Student Success and Retention." South African Journal of Higher Education 27(3): 330-352.

Wilson-Strydom, M. 2012. "Using the NTB's to Inform Institutional Understanding of under Preparedness: Implication for Admissions Criteria." South African Journal of Higher Education 26(1): 136-151.

Woloschuk, W., K. McLaughlin, and B. Wright. 2010. "Is Undergraduate Performance Predictive of Postgraduate Performance?" Teaching and Learning in Medicine 22(3): 202-204.

Wood, N. A. and M. M. Suriamurthee Maistry. 2014. "Professional Accounting Associations' Influence on Higher Education Accounting Pedagogy." Alternation Special Edition 12: 198-239.

Zimmerman, J., K. H. Brodersen, H. R. Heinmann and J. M. Buhmann. 2015. "A Model-Based Approach to Predicting Graduate-Level Performance Using Indicators of Undergraduate-Level Performance." Journal of Educational Data Mining 7(3): 151-176. 